\title{
The Chemical Engineers of Iowa State College
}

\section{Transforming Agricultural Wastes and an Institution, 1920-1940}

\author{
ALAN I MARCUS \\ ERIK LOKENSGARD
}

Iowa State College's chemical engineers, between the first and second world wars, identified service to agriculture as their primary purpose: This union of engineering and agriculture was highly unusual. Since its 1869 opening, the college's agricultural and engineering wings had squabbled. Instead of seeking common ground, agriculture professors and their engineering counterparts generally established distinct spheres of influence. As the college's faculty strove to demonstrate expertise and foster public constituencies, its engineering and agricultural sections tended to grow still further apart, and this pattern of separatebut-equal development often resulted in duplication of instructional effort. For example, agricultural mechanics was an agricultural course for years at Iowa State, but its content remained virtually indistinguishable from the college's course in mechanical engineering. More frequently, the competition between engineering and agriculture led to the creation of parallel institutions. Soon after the formation of an agricultural experiment station in 1887 demands arose for an engineering experiment station, and creation of an agricultural extension service immediately produced a movement for an engineering extension service. Iowa State was not atypical. The confusion that surrounded the Morrill Acts of 1862 and 1890, coupled with the desire to secure their shares of limited finances, caused engineer- 
ing and agriculture professors at virtually every land-grant college to establish and jealously guard their turf. ${ }^{1}$

The contests between college agriculture and engineering rarely erupted into fullblown, pitched battles. Support for these public institutions was too fragile to permit unseemly faculty displays. College success and, as a consequence the success of engineering and agricultural wings, usually demanded a modicum of civility between the opposing camps and even some cooperation. Often the contending forces could merely jockey for positions on the institutional totem. Despite the facade of cordiality and union, however, the situation at land-grant colleges in the late nineteenth and early twentieth centuries was clear: engineering and agriculture professors claimed different jurisdictional areas, recognized few subjects of mutual interest except institutional survival, and set about to do their business independent of each other. Even more to the point, college agriculture and engineering staffs stressed different missions and constituencies. Engineering faculties served industry while their agricultural brethren hoped to aid farmers. ${ }^{2}$

'For the situation at Iowa State, see R. A. Pearson, “Address to Grant Club, February 20, 1913," Raymond A. Pearson Papers, Special Collections, Iowa State University Library; Earle D. Ross, $A$ History of the Iowa State College of Agriculture and Mechanic Arts (Ames, 1942); Barton Morgan, $A$ History of the Extension Service of Iowa State College (Ames, 1934), 24-33; Christie Dailey, "Implementation of the Land-Grant Philosophy During the Early Years at Iowa Agricultural College, 1859-1890," (M.A. thesis, Iowa State University, 1982), 21-29; and Iowa State Board of Education, Biennial Report, 1912, 8-10, 335-339. For the situation at some other land-grant colleges see Morris Bishop, A History of Cornell (Ithaca, 1962); Monte A. Calvert, The Mechanical Engineer in America, 1830-1910 (Baltimore, 1967), 87-105; Merle Curti and Vernon Carstensen, The University of Wisconsin, 1848-1925: A History, 2 vols. (Madison, 1949), 1:459-475, 501-533, 2:374-410, 444-467; and Richard P. McCormick, Rutgers: A Bicentennial History (New Brunswick, 1966), 89-94, 118-122, 153-155, 174-185.

2James C. Casey, Kansas State University: The Quest for Identity (Lawrence, 1977), 39-47; Allen Nevins, The State Universities and Democracy (Urbana, 1962), 52-68; Dailey, "Implementation," 45-46. The annual meetings of the Association of American Agricultural Colleges and Experiment Stations provide particularly apt examples of engineering-agriculture tensions within land-grant schools. From the start, the agricultural element dominated this organization. The engineering wings of land-grant colleges continually sought entry to and representation within the association and the association repeatedly turned them away. In 1912, they ceased their efforts and formed instead a 
The efforts of Iowa State's chemical engineers after World War I marked a significant break with tradition. They led the way in bridging the gap between agriculture and engineering and, in the process, ushered in a new era of sustained cooperation between the two forces. Their labors at Iowa State created a model for harmonizing a college's engineering and agricultural wings. But the chemical engineers also had influence elsewhere. As Iowa State's chemical engineers resolved the engineeringagriculture split, they also attempted to lay groundwork for a new type of industrial and chemical production based exclusively on agricultural raw materials. They promoted new processes and techniques which soon found application in private enterprise and drew the attention and financial support of state and federal governments. In so doing, Iowa State's chemical engineers provided a basis for the integration of college faculties and opened the door for the development of a new partnership between agriculture and industry.

Before and during World War I, Iowa State's chemical engineers gave no indication that they would play these roles. Chemical engineering was but a recent addition to the college curriculum. The college introduced a few courses under the rubric "industrial chemistry" in 1910 and by 1913 it approved the practice of awarding undergraduate chemical engineering degrees, the first of which it granted a year later. During this nascent period, chemical engineering was exclusively aligned with the college's engineering camp. Charles A. Mann, professor in charge of chemical engineering, explicitly defined the province of his discipline in traditional terms. To Mann, chemical engineering consisted of five equally important areas: chemical manufacture, electrochemistry, metallurgical chemistry, gas manufacture, and food processing. Like his fellow engineers throughout the college, he emphasized research as the backbone of the engineering effort; it should be broadly gaugedeach of chemical engineering's five subsidivisions was equally valid-and pursued by both faculty and students. ${ }^{3}$

competitor, the Land-Grant College Engineering Association. Only in the 1920 s did these two rivals finally join forces.

${ }^{3}$ Minute Books of the Iowa State College Faculty, 6 May 1913; Charles A. Mann, "Chemical Engineering Course at Ames," Iowa Engineer 17 (1916), 86- 
Mann did more than talk; he put his vision into practice. In 1915 , he required undergraduates concentrating in chemical engineering to engage in research and prepare senior theses before they could receive bachelor's degrees, while two years later the college began to grant master's degrees-explicitly research degrees-in that discipline. Both the bachelor's and master's theses written prior to Armistice Day reflected Mann's commitment to wide-ranging research. No two of the eleven thesesnine by undergraduates-focused on a similar problem, nor were they, as a group, confined to a single branch of chemical engineering. The theses represented all five major divisions as students considered such diverse topics as the extraction of aluminum and iron sulfates from coal wash, the tensile strength of paint films, the conversion of paper-mill waste into cement, and the corrosion of iron. ${ }^{4}$

The college's president, Raymond Allen Pearson, shared Mann's enthusiasm for research. When Pearson came to Ames in 1912, his goal was to make Iowa State "comparable with such well known institutions as the Massachusetts Institute of Technology in Boston and Johns Hopkins University in Baltimore." To this end, he successfully pushed the college to establish a graduate school and to award the Ph.D. degree. But while Pearson and Mann held similar views of the necessity for scientific research at the college, they differed dramatically about appropriate research topics. Pearson's experience as assistant chief of the Department of Agriculture's (USDA) dairy division, professor of dairying at Cornell University, and commissioner of

87; Iowa State Board of Education, Biennial Report, 1914, 247 and 1918, 236.

"Undergraduate theses included E. F. Barnum, "The Recovery of Paper Mill Waste in the Form of White Portland Cement," 1915; R. S. McMullin, "A Study of the Condensation Products Formed in the Manufacture of Carburetted Water Gas," 1916; Harold P. Roberts, "The Elasticity and Tensile Strength of Paint Film," 1916; Hobart J. McKay, "Manufacturing Alcohol from Corncobs," 1916; Charles F. Ricker, "Production of Sodium Cyanide Utilizing Nitrogen of the Air," 1917; Homer C. Clarke, "The Extraction of Iron and Aluminum Sulphates from the Lakoata Coal Washery Dump," 1918; Leon C. Heckert, "The Formation of Toluene from Benzene-Xylene Mixture by the Use of the Friedel Crafts Reaction," 1918; A. L. McMillan; “Absorption of Carbon Monoxide from the Air by Charcoal under Atmospheric Conditions," 1918; and A. W. Pickford, "The Corrosion of Iron," 1918. Graduate theses included Werner J. Suer, "A Study of the Carbohydrates of the Corn Cob," 1917 and George H. Montillon, "The Production of Acetone from Corncobs," 1917. 
agriculture for the State of New York had colored his views. He saw improvement of agriculture as the college's primary mission and called on the entire faculty to contribute directly or indirectly to agricultural research. He repeatedly made clear this emphasis by referring to Iowa State as the public's "agricultural, scientific institution. ${ }^{\prime 5}$

A substantial segment of the faculty heeded the new president's call. Under Pearson's stewardship, agricultural history found its way into the curriculum, an agricultural economics department formed, and rural sociology gained programmatic status. Corn-breeding work became imbued with renewed vigor, veterinary medical research continued apace, and members of the agronomy department embarked on a soil-building program. Only the college's engineering wing did not follow the president's lead. Like Pearson, Iowa State's engineering professors accorded scientific research the highest priority. Unlike the president, however, they refused to place emphasis squarely on agriculture-related research. Like Mann, they defined their mission as industrial and considered in the broadest context. ${ }^{6}$

Pearson did little if anything to discourage the engineers' separate research efforts prior to America's involvement in World War I. He did not even interfere with Mann, who as head of the most recently formed division of engineering was particularly vulnerable. The situation did not change during the war, but shortly thereafter Mann resigned. Provided with the opportunity to make his own appointment, Pearson began to forge a link between engineering and agriculture. After temporarily entrusting chemical engineering to a caretaker, Pearson set out to find a suitable replacement. The college's board of regents seconded his idea to join engineering and agriculture. While allowing Pearson great latitude to select Mann's successor, the board reminded the president that it was "particularly desirous of having something done for the farmer." After an extensive search,

5Pearson, "Address to Grant Club"; R. A. Pearson, "The Work to be Done," Wallaces' Farmer 31 (20 December 1912), 8; “Address by President $R$. A. Pearson, of the Iowa Agricultural College," Iowa Yearbook of Agriculture, 1916, 415-417; lowa State Board of Education, Biennial Report, 1914, 277, 292-293.

'Iowa State Board of Education, Biennial Report, 1916, 227, 231-234, 245249, 254-255, 292-294; Ross, History, 274-287, 326-330. 
Pearson decided on Orland R. Sweeney, who accepted the offer and in 1920 took over the reins of the chemical engineering department. ${ }^{7}$

Sweeney seemed an especially promising choice. Although still a young man, he came to Iowa with a history of combining chemical engineering and agriculture. As an undergraduate at Ohio State University he had worked on the destructive distillation of corncobs. After he received his Ph.D. from the.University of Pennsylvania in 1916, his interest in the potential of farm materials accelerated. He took a position at North Dakota State College, where he not only erected a "paint fence" for the sytematic testing of linseed-oil-based paints but also investigated the possibility of substituting soybean oil for linseed. He even tried to develop a disposable baby diaper composed of peat. Although the Kotex company expressed interest in Sweeney's creation, it chose not to make the product. ${ }^{8}$

Sweeney's efforts prior to his arrival in Ames suggested his orientation. Each dealt with agricultural waste materials, which would prove to the the major theme of his Iowa State work. He hoped to take "something that nobody else wants" and work "on it to make something useful." The notion that industries based on agricultural wastes would boost farm incomes loomed prominently in Sweeney's thinking. Such industries would allow farmers to turn what had been waste into profits and with little additional expense. He boldly predicted that these new industries could provide farmers an extra billion dollars a year. Thus Sweeney's view of chemical engineering research at Iowa State differed from his predecessor's. He set his focus almost exclusively on chemical manufacture and within that area stressed farm wastes as raw materials. As he expressed it in a publication aimed at students, emphasis in chemical engineering at Iowa State would be "laid upon the economic recovery of by-

7"Prominent Chemical Expert Will Head Department Here," Iowa State Student, 29 September 1920, 5; "He Invented an Industry," The Milepost 2 (16 October 1930), 27.

${ }^{8}$ O. R. Sweeney and H. A. Webber, ${ }^{4}$ Experimental Studies on the Destructive Distillation of Corncobs," Iowa Engineering Experiment Station Bulletin \#107 (Ames, 1931), 6; Sweeney to T. R. Agg, 28 January 1936, Orland R. Sweeney Papers, Special Collections, Iowa State University Library; Sweeney to S. W. Smith, 13. April 1934,. Sweeney Papers; Harry S. Morgan, "Molders of Men-O. R. Sweeney," Iowa Engineer 38 (1938), 170. 
products, especially the large amounts of waste material resulting in agriculture, and the industries utilizing agricultural products. ${ }^{.9}$

It was remarkable that a member of the college's engineering wing wanted to unite with its agricultural side. Choices for senior thesis topics in chemical engineering were the most immediate manifestation of Sweeney's program. Of the thirty-two theses written during his first three years, at least twenty-six explored some industrial use for agricultural wastes. These thesis topics indicated a profound change in the college's chemical engineering department. Before Sweeney assumed control, only one graduate and one undergraduate examined subjects that touched on agriculture. These theses did not spark an engineering-agriculture linkage at the college or any attempt to develop sustaining industries based on farm products. Instead, the necessities of war and the very real threat that America would be isolated from its European resources had inspired these theses. Their authors recognized that they were pursuing topics which chemical engineers did not usually broach, as George H. Montillon's apologia reflected. Montillon's master's thesis began with a defense of his research on the production of acetone from corncobs. Montillon admitted that he had selected a nontraditional subject but argued that "at the present time acetone is in great demand due to its extended use in war industries" and as a consequence, "every possible source of this product should be investigated." 10

ORLAND R. SWEENEY was determined to reorient the chemical engineering faculty. None of the department's continuing members chose to engage in agricultural waste research and all left

${ }^{9}$ Iowa State Student, 29 September 1920; O. R. Sweeney, "Chemical Engineering," Iowa Engineer 21 (May 1921), 5; O. R. Sweeney, "Utilization of Agricultural Products," speech draft, 3 December 1937, Sweeney Papers; "Cornstalk Cellulose Industry Assumes Gigantic Proportions," Current Topics (1928), 3; O. R. Sweeney, "Possibilities in Manufacturing By-Products of Corn," Iowa Yearbook of Agriculture, 1926, 21-22.

${ }^{10}$ Montillon, "Production of Acetone," 3. A typescript list of chemical engineering theses done prior to 1933 is available at the Iowa State University $\mathrm{Li}$ brary. See Lionel K. Arnold, comp., "An Annotated Check List of Chemical Engineering Theses from Iowa State College" (39 pp.) and "Supplementary Check List of Chemical Engineering Theses" (8 pp.). 
within a few years of Sweeney's appointment. He replaced them with former graduate students, who had done their theses on agricultural waste industries. After this initial housecleaning, Sweeney did not let up. During the interwar period, those faculty members who did not share Sweeney's commitment to the creation of farm-waste-based industries did not remain in Ames. Dabbling in this research was not enough; those who stayed on the periphery rather than placing farm-waste research as their top priority soon went elsewhere. Conversely, those who accepted Sweeney's vision often had exceptionally long tenures at Iowa State. For example, H. A. Webber and L. K. Arnold both signed on the mid-1920s, diligently pursued farm-waste studies, and remained at the college for over three decades. ${ }^{11}$

Sweeney, then, made over the chemical engineering department in his own image. The work there consistently showed his influence as it developed through several phases. His crew sorted out options by first investigating, in the early 1920s, the commercial possibilities of a wide variety of agricultural wastes. Sweeney, his colleagues, and their students fermented beet sugar pulp to produce alcohol, acetic and butyric acids, and paper pulp, and recovered pectin from the extracts of apple and beet processes. They also explored plastics made from peanut, cottonseed, and oak hulls, and from straw and they tried to hydrogenate cottonseed oil. Yet these early years were the "era of the corncob" because Sweeney and his cohorts quickly decided to devote themselves to its potential uses. They destructively distilled, pulverized, chemically digested, and fermented cobs to produce such basic industrial chemicals as acetone, furfural, charcoal, acetic acid, methanol, oxalic acid, calcium acetate, and formic acid. Their initial results led them to conclude that corncobs might become the source of raw materials for entire industries. Prospects seemed so promising that a Des Moines Register reporter visited the campus in 1923, learned of the chemical engineers' research, and gushed that "silk hose, fabric dyes, camera film, 'amber,' stemmed pipes, hot water bottles, chicken

${ }^{11}$ For rosters of the chemical engineering staff, see the following pages in the biennial reports of the Iowa State Board of Education: 1922-210, $1924-185,1926-253,1928-318,1930-324,341$, and $1932-279$. Aside from Arnold and Webber, no chemical engineer remained a member of Sweeney's department for more than four years. 
feed, and gas mantles are but some of the various objects which can be made from corn cobs." 12

Despite the appearance of hyperbole, the Register's report was not nearly broad enough. In addition to the mentioned substances, the chemical engineers used corncob derivatives in the early 1920 s for the small-scale production of punk, incense, white lead, vinegar, activated filters for gas works, and water softeners. Demonstrating that chemical engineering could produce a wide range of substances from corncobs, however, amounted to little more than a public-relations campaign. It created interest in the work but did not further it. The agricultural waste utilization program rested not on possibilities but on commercial application; the chemical engineers needed to show that isolating a particular substance or manufacturing a specific article would be cost effective. This stipulation required them to narrow their vision and concentrate on industrial materials most likely to prove commercially successful. It also demanded that they establish in their laboratories small production plants. Only by considering a process from corncobs to final product could they anticipate the costs of large-scale manufacture and compare those expenses with alternative industrial practices. ${ }^{13}$

\footnotetext{
${ }^{12}$ Chemical engineering theses from these initial research projects include J. A. Hovsepian, "Studies on Pentosan Plastics," 1924; James M. Williamson, "Production of Plastics from Oak Hulls," 1923; Ted Bergman, "Utilization of Beet Sugar Pulp," 1921; Verne Hass and Tom Gilbert, "The Utilization of Sugar Beet Pulp," 1922; F. J. Mleynek, "The Recovery of Pectin From Fruit Wastes," 1923; and H. L. Shepard and H. A. Howell, "Auto-Catalysis in the Hydrogenation of Cotton Seed Oil," 1921. For work on corncob utilization see O. R. Sweeney, "The Commercial Utilization of Corncobs," Iowa Engineering Experiment Station Bulletin \#73 (Ames, 1924) and the following chemical engineering theses: G. W. Burke, "Some Analytical Data On Corn Cobs and Their Parts," 1923; L. K. Arnold, K. L. Wagner, and H. G. Goldschmidt, "A Study of the Destructive Distillation of Corncobs," 1921; G. P. Patterson and H. P. Bigler, "Destructive Distillation of Corn Cobs," 1922; L. M. Christensen, "A Study of the Utilization of Corn Cobs by Fermentation," 1923; George M. Russell and Harvey C. Morris, "The Production of Vinegar," 1922; L. J. Botleman and R. R. Wagner, "Preparation of Furfural From Corn Cobs On a Commercial Scale," 1921; and Richard L. Hanson and Jack W. Hussey, "A Study of the Production of Calcium Acetate from Corncobs," 1923. See also Ruth Cromer, "How To Make Money from Iowa Corn Cobs," Des Moines Register, 7 October 1923; "Chemists Create Useful Materials from Corncobs" and "Lowly Corncob Furnishes Many.Unsuspected Daily Products," Iowa State Student 15 April 1921, 1 and 24 January 1921, 3.

${ }^{13}$ Relevant chemical engineering theses include R. P. Moscrip, "Studies in
} 
The chemical engineers labored within this utilitarian framework and during this early period devoted most attention to six corncob-based substances. Of these, furfural was the object of greatest experimentation. Prior to the work at Iowa State, furfural remained little more than a laboratory curiosity. Selling for about thirty dollars a pound, this light yellow, oily material's cost made prolonged investigations of its nature almost prohibitive. The Ames engineers found, however, that the destructive distillation of corncobs liberated substantial quantities of the substance. They not only refined furfural production techniques and designed blueprints for commercial facilities, but also set about to determine furfural's potential industrial uses. They explored furfural as a motor fuel, embalming fluid, reducing agent, illuminant, anti-knock additive, source for activated carbon, and base for dyes. Though extensive, these inquiries did not result in the creation of new furfural-based industries. Although the chemical engineers had demonstrated that furfural had many uses, they concluded that in no instance was it sufficiently superior to supplant existing industrial chemicals. More important, the engineers learned as they studied furfural that the Quaker Oats Company had developed a process of producing the substance from oat hulls and was planning to open a production facility in conjunction with its Cedar Rapids oatmeal plant. While corncob and oat hull furfural production costs were about the same, the Quaker Oats factory would possess a competitive advantage. It could produce the substance more economically because it did not have to gather its raw material separately. Corncob furfural would be marketable only if lowa State's chemical engineers developed new, cheaper production techniques or if a dramatic new use for the chemical caused demand to exceed Quaker Oats' ability to produce it. ${ }^{14}$

Corn Cobs," 1922; George T. Williams, "The Commercial Utilization of Corncobs," 1923; Kenneth M. Vaughn, "Utilization of Corncob Alkali Fusions in Water Softening," 1926; and Robert E. Fothergill and Ronald L. McVey, "A Study of the Methods for Reducing Corncobs to Various Degrees of Fineness and the Utilization of the Ground Material," 1924.

${ }^{14}$ Chemical engineering theses useful on these points include J. P. Bishop and D. L. Gilbert, "The Preparation of Furfural From Corncobs," 1921; L. N. Haugen and E. J. Kowalke, "Further Investigations on the Commercial Production of Furfural From Corn Cobs," 1923; Galen Hunt, Philip C. 
The chemical engineers' examination of other corncob derivatives was almost as thorough. After isolating a corncob pentosan, they tried to produce from the substance a new plastic. Although initial results appeared encouraging, more detailed tests confirmed that corncob plastic could not compete physically or economically with available materials. A similar frustration characterized their oxalic acid work. To be sure, oxalic acid had a number of commercial applications in the artificial silk, celluloid, dye, and explosive industries. But while the Ames engineers demonstrated that they could recover the acid from corncobs, they were unable to manufacture it cheaply enough to interest commercial producers. Xylose, a corncob pentose, also proved to be easy to isolate but seemed to hold few commercial possibilities. The chemical engineers experimented with it as an adhesive and suggested it as a table-sugar substitute for diabetics. No investor expressed interest in the artificial sweetener, however. The engineers next turned to corncobs as a source of synthetic chicle. Using the heaviest, most resilient portions of the destructively distilled cobs, they thought the material so promising that they took it to William Wrigley, Sr., to explore its possibilities as a base for chewing gum. While Wrigley welcomed the Ames entourage, he complained about the substance's burnt taste. Although Sweeney persisted in chewing it "off and on for about a week," he found that the taste remained strong. Other more conventional attempts to remove the pungent flavor also failed. ${ }^{15}$

Jones, and Thalmer J. Thompson, "The Preparation of Activated Carbon From Furfural Residues," 1924; H. M. Wolcott, "Possible Use of Furfural as a Motor Fuel," 1923; and Paul Bruins, "Commercial Utilization of Agricultural Wastes," 1927. See also Sweeney's retrospective comments on furfural and Quaker Oats: Sweeney to Elizabeth L. MacHatton, 11 November 1943; Carl S. Miner to Sweeney, 26 February 1946; and Sweeney to Miner, 1 March 1946 , all in Sweeney Papers.

${ }^{15}$ Relevant chemical engineering theses on conversion to plastic include Herbert L. Bowers, "A Study of Synthetic Resins from Pentosan Materials," 1924; Albert J. Duden, "Properties of Corn Cob Plastics," 1925; Joseph A. Hovsepian, "Studies on Pentosan Plastics," 1924; and J. E. McFarland, "Plastic Condensation Products From Pentosan-Containing Materials," 1924. These on oxalic acid included Ralph M. Cash and Gaylen Sayler, "Preparation of Oxalic Acid from Corn Cobs," 1922; Raleigh L. Farlow, "Preparation of Oxalic Acid From Corncobs," 1923; Ralph A. Trexel, "Fur- 
Corncob charcoal was the final cob-derived substance scrutinized in detail. The chemical engineers had more limited ambitions for this substance. Rather than expect its acceptance as the source material for a national industry, they targeted corncob char as an inexpensive replacement for wood charcoal in the wood-poor Midwest. After finding the material cheap and easy to produce, they demonstrated its versatility by using it to caseharden steel and as a decolorizing agent in sugar refining. Their most sustained effort was to get midwestern gunpowder manufacturers to employ it as a substitute for wood charcoal and they did more than merely produce the substance. While not claiming to be "powder experts," they nonetheless managed to mix their own corncob powder and "succeeded in loading a shell and shooting a rabbit." They then contacted Western Cartridge Company in East Alton, Illinois, presented their case, and waited for the company's reaction. Western Cartridge dismissed corncob char as impractical, but found Iowa State's efforts intriguing. Sweeney seized upon this expression of interest as an opportunity to involve the company in new research on the use of cornstalks. He reminded the company that cornstalks contained a high percentage of cellulose which they could convert into smokeless powder-nitrocellulose-rather simply; cornstalks could constitute the raw material upon which to base' a segment of the munitions industry. Sweeney's argument apparently impressed Western Cartridge because it provided Iowa State with a grant to fund cornstalk research. ${ }^{16}$

Western Cartridge's grant marked the beginning of the corn-

ther Studies on the Production of Oxalic Acid from Corn Cobs," 1923; and Henry A. Webber, "Studies on the Production of Oxalic Acid from Corn Cobs and Stalks," 1925. Theses on xylose included D. R. Kiser, "The Manufacture of Crude Xylose From Corncobs," 1925; W. E. Rouser, "Manufacture of Xylose From Corncobs," 1925; and Julian Toulosue, "Xylose From Corn Cobs," 1926. Sweeney discussed the chicle work retrospectively in Sweeney to L. W. Marble, chief chemist, Frank H. Fleet Corporation, 19 July 1939, and Sweeney to Robert $L$. Wilson, director of research, William Wrigley Company, 6 August 1942, both in Sweeney Papers.

${ }^{16}$ Sweeney, "Possibilities in Manufacturing" (see fn. 9), 25; Sweeney to H. F. Smith, Smith Gas Engineering Company, 14 May 1926, Sweeney to Western Cartridge Company, 4 September 1925, both in Sweeney Papers. Sweeney summarized much of the early corncob work at lowa State in "The Commercial Utilization of Corncobs," Iowa Engineering Experiment Station Bulletin \#73 (Ames, 1924). See also Lionel K. Arnold, History of the Department of Chemical Engineering at Iowa State University (Ames, 1970), 25. 
stalk research era at Iowa State. Yet the chemical engineers did not abandon corncobs entirely, although they did cut back significantly on this original emphasis. During the late 1920s and early 1930s, most of the cob work revolved around furfural production techniques and the exploration of the substance's potential commercial uses. They examined its possibilities as a rubber vulcanizer, softener, and solvent; a base for a plastic unlike the earlier pentosans; and a varnish resin.. They also tried cracking the chemical to see if the process's products might possess commercial application. They had not waited until after 1925 to begin their first cornstalk utilization studies. Some preliminary investigations occurred a few years earlier, and by 1925, the Ames group had established three main techniques for breaking the stalks into fibers: steam under pressure; mechanical manipulation and beating; and chemical digestion. The engineers also had begun to discuss the possibilities that cornstalks could become raw material for paper manufacture, cellulosebased explosives, and a synthetic lumber industry. But cornstalk research had progressed slowly before 1925 because it was expensive; it required special equipment on a large scale. Western Cartridge's grant helped the chemical engineers surmount that hurdle. It provided funding not only for salaries but also for equipment. ${ }^{17}$

Western Cartridge was first to award the chemical engineers outside support, but the engineers were sensitive to the need for publicity much earlier and not just because it might bring additional research funds. Almost from their start, they understood that the success of their agricultural waste utilization crusade

${ }^{17}$ Chemical engineering theses that considered furfural during this period included Paul F. Bruins, "Application of Furfural and Its Derivatives to Manufacturing Plastics," 1930; Richard W. Bruins, "The Physical Properties of a Furfural Plastic," 1930; Jacob D. Green, "Pyrolysis of Furfural," 1931; Lyle K. Huhn, "Studies on the Products From Furfúral Cracking," 1931; Robert V. Janda, "The Cracking of Furfural," 1931; and Lawrence G. Mason, "A Study of the Action of the Products Obtained From the Maize Plant in Rubber Compounds as Fillers, Softeners, Accelerators and Agars," 1928. Early chemical engineering cornstalk utilization theses included Richard Ericson, "Experiment with Furfural Yields from Corncobs and Cornstalks," 1925, and Oscar Tow, "The Production of Paper From Iowa Cornstalks," 1925. Also see Lionel K. Arnold, "Cornstalks as an Industrial Raw Material," Agricultural Engineering 9 (1928), 379-380 and "Making Insulating Boards From Cornstalks," Cellulose 1 (1930), 272-275. 
depended as much on promotional activities as it did on engineering efforts. Without creating interest in, excitement about, and markets for their waste-based productions, they could not convince industries to switch raw materials, adopt novel techniques, and reorganize production facilities. lowa State's engineers had to publicize their work and stress its economic benefits to industry whenever possible. Their initial public relations venture took place in 1922 at the Iowa State Fair. Chemical engineering students under the watchful eyes of their professors set up a display and distributed incense, plastic plaques, and other corncob products. They intensified their campaign at these annual events in subsequent years. Hoping "to introduce something exotic," the students demonstrated one year that they could produce dyes from corncobs; they dyed "a number of white rats all sorts and kinds of colors." By about 1925, cornstalk products began to take their place next to corncobs. In that year, students constructed their fair booth from cornstalk lumber and decorated the interior with cornstalk tiles. These shows advertised the chemical engineers' work in Iowa and gave them some national publicity, but the real break came in 1927. Iowa State's engineers were invited to display their wares at the Eleventh Annual Exhibition of Chemical Industries in New York. Exhibiting hundreds of corncob and cornstalk products, the chemical engineers suddenly burst into national prominence. "New York newspapers featured [our exhibit]," Sweeney later wrote, "and Sunday supplements went all over the United States. ${ }^{\text {18 }}$

National ReCognition for Iowa State's chemical engineers paid off in several says. On the most basic level, they assumed new power within the college's engineering wing. Sweeney's salary was higher than any other department head in the division and more graduate students pursued advanced degrees in his department than in any other engineering discipline. The chemical engineers became a significant voice-perhaps the most significant-in the college's engineering experiment station. Those among them who affiliated with the station outnumbered any other single engineering group by at least two to one. Also,

${ }^{18}$ Sweeney recounted public relations efforts in Sweeney to H. E. Barnard, director of research, National Farm Chemurgic Council, 7 May 1940, Sweeney Papers. 
the station began in 1927 to devote an impressively large portion of its annual budget to agricultural waste utilization research and published at least eight separate bulletins on the subject. The Iowa State Engineering Extension Service also fell quickly in line. It issued several popularly written bulletins aimed at farmers and businessmen which featured prominently the chemical engineers' accomplishments. The chemical engineers' new clout even extended throughout the college. When the state board of education presented its biennial requests for college funds in 1926 and especially 1928, it highlighted the chemical engineers' agricultural waste research and argued that the department's activities justified additional college expenditures. In 1927, the board had Sweeney address a banquet for the state legislature and discuss his vision of the "greater industrial development" of the state through "intensive utilization of agricultural wastes." The college administration soon called the chemical engineers' labors those "of the very greatest importance to lowa and the nation." This sentiment translated into tangible benefits for the chemical engineers. ${ }^{19}$

In the same year that they emerged as a major force in experiment station affairs, the chemical engineers asked for and received a new building expressly for farm-waste investigations. They drew on their new prestige to equip the facility with outside support. The National Bureau of Standards was their target. Sweeney met with Herbert Hoover, then secretary of commerce, and G. K. Burgess, director of the bureau, to argue his case, and

${ }^{19}$ Iowa State Board of Education, Biennial Report, 1926, 253, and Biennial Report, 1928, 285. The engineering experiment station published a list of staff members with each bulletin. The chemical engineers never had less than four people on staff, while no other engineering division had more than two. For the station bulletins, see O. R. Sweeney and L. K. Arnold, "Cornstalks as an Industrial Raw Material," \#98, 1930; "The Production of Paper from Cornstalks," \#100, 1930; and "Studies on the Manufacture of Insulating Board," \#136, 1937; O. R. Sweeney, C. E. Hartford, R. W. Richardson, and E. R. Whittemore, "Experimental Studies on the Production of Insulating Board from Cornstalks," \#102, 1931; O. R. Sweeney and H. A. Webber, "Experimental Studies on the Destructive Distillation of Corncobs," \#107, 1931; H. A. Webber, "The Production of Oxalic Acid from Cellulosic Agricultural Materials," \#118, 1934; L. K. Arnold, H. J. Plagge, and D. E. Anderson, "Cornstalk Acoustical Board," \#137, 1937. Extension service bulletins included L. K. Arnold, "Utilization of Agricultural Wastes," \#99, 1928, and "Utilization of Agricultural Wastes and Surpluses," \#113, 1933; and O. R. Sweeney, J. H. Arnold, and L. K. Arnold, "Processing the Soybean," \#103, 1929. 
received a large grant to outfit the new structure. Hoover and Burgess found Sweeney's program so compelling that in the next year they established a bureau research team in Ames to work in tandem with the college's chemical engineers on cornstalk fiber-board production. The National Bureau of Standards was not the only federal agency swept up by the excitement in Ames. The USDA Bureau of Chemistry and Soils reported on the research as early as 1928 , became involved in its own investigation in 1931, formed a new farm by-product section in 1932, and created an agricultural by-products laboratory a year later. The bureau chose to locate the lab at Iowa State. Featuring larger, more modern facilities, the laboratory's staff worked with the college's chemical engineers on destructive distillation techniques, fermentation processes, and cornstalk paper manufacture. ${ }^{20}$

While governmental largess indicated that Iowa State's chemical engineers had won a national reputation, there were other signs as well. In the late 1920 s, legislators from states as distant

${ }^{20}$ "Cyrenus Cole on the Utilization of Agricultural Wastes;" speech delivered to the U. S. House of Representatives, 25 January 1927, Sweeney Papers; Sweeney to S. A. Knapp, 13 May 1936, Sweeney Papers; Virgil W. Anderson, "Ahead of the Field," Iowa Engineer 37 (1937), 127; Warren E. Emley, "Processes for Industrial Use of Corn Stalks Are Developed," United States Daily, 21 January 1931, 7; Iowa State Board of Education, Biennial Report, 1926, 21, and Biennial Report, 1928, 56-61; O. R. Sweeney, "Greater Industrial Development of Iowa by More Intensive Utilization of Agricultural Wastes," banquet address delivered to officials and legislators, 18 February 1927, Sweeney Papers; R. M. Hughes, Address . . September 17, 1930,29; C. E. Hartford, "Manufacture and Properties of a Cellulose Product (Maizolith) From Cornstalks and Corncobs," National Bureau of Standards Miscellaneous Publication \#108, 1030; O. R. Sweeney and W. E. Emley, "Manufacture of Insulating Board From Cornstalks," National Bureau of Standards Miscellaneous Publication \#112, 1930; George K. Burgess, director, Bureau of Standards, "Annual Report, 1930," National Bureau of Standards Miscellaneous Publication \#115, 1930, 44-45; Lionel K. Arnold, “Chemical Engineering Building at Iowa State College," Journal of Chemical Engineering 6 (1929), 292-298; USDA Bureau of Chemistry and Soils, Report of the Chief, 1928, 30; 1930, 2; 1932, 14; 1934,8 . For the bureau's research see H. G. Knight, "Industrial Utilization of Farm Products," Condensed Proceedings of the Southern Chemurgic Conference 69 (1936), 8-14; H. T. Herrick, "The Research Program of the Bureau of Chemistry and Soils on Industrial Utilization of Farm Products," Proceedings of the American Soybean Association, 1937, 3-9; and T. R. McElhinney, B. M. Becker, and P. B. Jacobs, "Destructive Distillation of Corncobs: Effect of Temperature on Yields of Products," Industrial and Engineering Chemistry 30 (1938), 697-701. 
as Georgia were writing to Sweeney and his colleagues for additional information on their research and its applicability to their states. Foreign governments also contacted the chemical engineers. Representatives of Australia, Argentina, Britain, Hungary, and Germany requested information and engineers to establish plants in their countries. The Soviet Union went further. In 1929, it sent two men to Ames to examine the engineers' facilities and to learn their practices. American businessmen and innovators also inquired into the Ames research. Thomas Edison and Henry Ford were among the most prominent industrialists to correspond with Sweeney and his cohorts. Sometimes the college's engineers were asked to address industrial concerns. For example, in 1930 General Electric invited Sweeney to discuss how the company could use agricultural waste products in its operations. Among the substances that he proposed were cornstalk lignin as a substitute for shellac, corncob glue, and the employment of pressed cornstalk boards in transformers. Sweeney also found himself representing Iowa State's chemical engineers on prestigious panels. In one instance he shared the platform with such notables as General Motors. Chairman Alfred P. Sloan, FBI Director J. Edgar Hoover, and Prime Minister W. L. McKenzie of Canada. ${ }^{21}$

By the late 1920s, Ames's chemical engineers had acquired an international reputation and federal connections. Their research during this period kept pace with their fame. Cornstalk paper was one substance that captured the chemical engineers' imaginations. They managed to produce a good quality paper pulp from the stalks and established principles for large-scale cornstalk manufacture. In 1929, several regional newspapers dramatized the work by producing cornstalk specials. Newspapers printed on cornstalk paper called attention to the college but were too costly to become anything but a curiosity. The Ames group persisted in refining the pulp-making process but was

${ }^{21}$ "Russian Government Attracted by Cornstalk Process," Iowa Engineer 29 (1919), 26; Sweeney to Mrs. R. C. Good, 2 October 1929, Eugene Matrosow to Sweeney, 20 May 1930, W. W. Larsen to Sweeney, 20 May 1930, Sweeney to E. G. Liebold, general secretary to Henry Ford, 15 February 1933; Sweeney to Professor W. H. Stevenson, 15 July 1931, Sweeney to T. R. Agg, 25 November 1930 , all in Sweeney Papers. "Dr. Sweeney Speaks to Insurance Presidents," Iowa Engineer 38 (December 1937), 66. Sweeney's letter to Liebold discusses his previous conversations with Ford and Edison. 
unable to make a cornstalk material competitive with wood paper. Its investigations into alpha cellulose production came to the same end. Although the chemical engineers could make a high-grade alpha cellulose-the base for rayon-from stalks, the cost of the process made commercial manufacture unrealistic. ${ }^{22}$

Other forms of cornstalk pulp seemed more promising. Chemical digestion of stalks in caustic soda yielded a jelly-like pulp which could be molded. Called maizolith-cornstonethe substance was exceedingly dense and a good electrical insulator. Sweeney and his crew projected that it would make "knife handles, switch buttons, knobs, gears," and other high-stress objects. They were even more optimistic about the pulp-like material that resulted from attacking cornstalks with pressurized steam. The engineers found that they could combine this material to form synthetic lumber of varying densities. Their productions ranged from substitutes for cork, which initially interested refrigerator manufacturers, to a hard, dense board suitable for "the construction of automobile bodies, truck bodies, [and] Pullman cars." The pressurized steam process possessed an additional advantage. Its waste water contained a high percentage of

${ }^{22}$ Theses on paper pulp from cornstalks include Lionel K. Arnold, "The Elaboration of Corn Stalks into Paper Pulp," 1926; Lionel K. Arnold, "Cornstalks as a Raw Material for Paper Production," 1930; Stanley J. Hultman, “Cornstalk Pulp by the Sulphite Process," 1930; Ralph H. Riemenschneider and Stuart M. Garstren, "Studies in the'Manufacture of Paper from Cornstalks," 1926; William Roberts, “A Study of the DaVains Process for Making Paper from Cornstalks," 1927; Chitao P. H. Tan, "Corn-Stalks as a Raw Material for Paper Manufacture," 1926; William Perry Wood, Jr., "Some Chemical and Physical Properties of Various Cornstalk Papers," 1928. For some cornstalk specials, see the Webster City Daily Freeman-Journal, 28 March 1929; Spencer News-Herald, 28 February 1929; and the Huron (South Dakota) Evening Huronite, 10 January 1929. Also see Sweeney to Frank E. Deem, A. J. Brandt, Inc., 4 April 1931; Sweeney to E. Jerome Dyer, London, 30 March 1931, both in Sweeney Papers; Lionel K. Arnold, "Cornstalks as a Papermaking Material," Paper Trade 53 (1927), 3-5, and "Paper from Cornstalks," Cellulose 1 (1930), 224-227. On cellulose see H. A. Webber, "Cellulose from Cornstalks," Industrial and Engineering Chemistry 21 (1929), 269-271. Theses included Clark Bright, "A Study of the Methods of Preparing High Alpha Cellulose From Cornstalks," 1928; Frank P. Fowler, "Nitric Acid Hydrolysis of Corn Stalks," 1928; Charles A. Funk and Carrell O. Turner, "Studies on the Isolation of Cellulose from Corn Stalks by Chlorination," 1929; and Darwin H. Huff, "Studies on the Isolation of Corn Stalk Cellulose with Dilute Nitric Acid," 1929. 
organic matter which, when collected, could serve as a source of raw materials for other industries. ${ }^{23}$

Perhaps because they could produce two commercial substances from one basic process, the chemical engineers emphasized cornstalk board manufacturing. Their most sustained research focused on cornstalk insulation board, a choice which reflected commercial realities. The extant insulation board industry was a synthetic lumber industry. The two most common insulation boards, Insoboard and Celotex, were composed of straw and sugar cane bagasse respectively. With an already established market for synthetic insulation lumber, Ames's chemical engineers did not face the problem of justifying the use of an artificial material. They only needed to produce cornstalk insulation board more cheaply than competitors, and the prospect that the process's waste water-cook liquor-would also hold commercial application made it more likely that the cost of cornstalk insulation board could undercut Celotex and Insoboard. In this hope the Iowa State group worked in two complementary directions. The engineers explored manufacturing and drying techniques for cornstalk insulation board, and also desperately sought commercial uses for the liquor. The latter endeavor was far ranging. The chemical engineers examined cook liquor as a source of natural gas, flotation oils, oxalic acid, lignin, xylose, polyhydroxyl alcohols, and adhesives. They even tried it as a road binder. ${ }^{24}$

${ }^{23}$ Arnold, "Utilization of Agricultural Wastes," (see fn 19), 8. Maizolith theses by chemical engineers included Jack W. Eichinger, "The Production of Cellulith From Cornstalks and Corncobs," 1926; Charles Hartford, "The Manufacture of Cellulith From Cornstalks and Corncobs," 1928; Ronald J. Berkhimer, "The Waterproofing of Maizolith," 1929; Jacob D. Matlack and John M. Sharf, "Drying and Molding of Maizolith," 1931. Synthetic lumber theses included John S. Reece, "Synthetic Lumber From Cornstalks," 1928; Paul A. Leightle, "Miscellaneous Studies on Water Proofing of Synthetic Lumber From Cornstalks," 1929; and J. L. McMurphy, "The Sizing and Waterproofing of Press Boards Made from Cornstalks," 1930. Also see O. R. Sweeney and Robley Winfrey, "The Production of Synthetic Lumber From Cornstalks," Mechanical Engineering 52 (1930), 848-851.

${ }^{24}$ Arnold, "Utilization of Agricultural Wastes," 7; Sweeney, "Possibilities in Manufacturing By-Products of Corn," (see fn 9), 23-24. Theses on cornstalk lumber included Roy A. Loomer, "The Production of Synthetic Lumber form Corn Stalks and Plaster of Paris," 1927; Murray B. Peterson, "Apparatus for the Control of the Process Used in the Manufacture of Synthetic Lumber," 1929; 
The chemical engineers did more than experiment; they also tried to involve industry. Sweeney was particularly aggressive and almost immediately successful. In 1927 a group of Chicago businessmen established Maizewood Products to manufacture cornstalk insulation boards. Although he remained in Ames, Sweeney served as informal consultant to the firm and lent his considerable prestige to its effort. His business acumen unfortunately did not match his scientific talents, however, and the company was undercapitalized from the start. Construction on its production facility in Dubuque began in 1927 but because of financial difficulties was not complete until late in 1929. Almost simultaneously with the plant's opening and production of the first boards-they came four feet wide, seven-sixteenths of an inch thick, and eight, nine, or ten feet long - the company went into receivership. It had exhausted its limited funds. ${ }^{25}$

The receivers did not disband the company but sought new ownership. They prevailed on Sweeney to take complete charge of production while the search was underway. He agreed, and his reputation as well as, by implication, the reputation of Iowa State's chemical engineers, soon paid dividends. Their faith in cornstalk insulation board had attracted several prominent Iowans who in 1930 established a holding company, National Cornstalk Processes, to take over Maizewood. The investors who provided the then impressive sun of one million dollars included Henry A. Wallace, soon to become secretary of agriculture; Frank O. Lowden, former governor of Illinois; and Herbert F. Perkins, president of International Harvester. The new owners moved swiftly; the contacted Sweeney and asked him to reorganize the Dubuque plant. Sweeney revamped the established

Hubert C. Richardson, "The Production of a Thermal Insulating Material of Low Conductivity from Corn Stalks," 1929; Robert W. Richardson, "Development of Synthetic Lumber from Cornstalks," 1.930; G. M. Seidel, "The Production of Synthetic Lumber From Cornstalks," 1927; and Herbert L. Stiles, "The Thermal Conductivity of Corn Stalk Products," 1929. Cook liquor theses included Willett J. McCortney, "Composition of Cornstalk Cook Liquors," 1927; Norman F. Kruse and James A. Shea, "The Recovery of Lignin from Cooked Cornstalk Liquor," 1929; Theodore R. Naffziger, "Plans and Specifications of a Plant for the Manufacture of Adhesive from the Wastes of the Corn Plant," 1928; and James.W. Beach, "Cook Liquor as.a Core Binder," 1931.

${ }^{25}$ Sweeney to Herman Manufacturing Company, Lancaster, Ohio, 18 November 1929, Sweeney Papers. 
production techniques and added new ones; he employed the latest processes which Iowa State's chemical engineers had uncovered, some of which they had not yet even patented. His work produced dramatic results. By 1932, Maizewood was turning out roughly seventy thousand feet of cornstalk insulation board per day. Among its clients was the Chicago World's Fair. Maizewood insulating board was used in the fair's administration building and featured prominently, which yielded excellent publicity for both the firm and lowa State. ${ }^{26}$

CORNSTALK INSULATION BOARD was the first modestly successful agricultural waste product devised at Iowa State. Yet even before Maizewood, the chemical engineers had demonstrated the manifold possibilities of farm wastes and the excitement of their labors had rubbed off on their colleagues. As the chemical engineers had gained both standing within the college and a national following, members of other departments had gravitated to the agricultural waste program. Several had become active, if occasional, participants. For instance, in 1928 the agricultural experiment station's J. B. Davidson and E. V. Collins developed a cornstalk harvester. R. M. Hixon and C. J. Peterson of the college's chemistry department moved to agricultural wastes the next year. They investigated the chemical composition of cornstalk tissue. In 1929 members of the bacteriology department set their students to studying the bacteria instrumental in the fermentation of cornstalks. Each effort was independent of the chemical engineers, but agricultural waste utilization research became an activity around which a substantial portion of the faculty rallied. In this sense, it fulfilled the departed Pearson's dream-he resigned in 1926-of agricultural research as the college's primary mission. During the 1930 s it would also usher in an unprecedented period of interdepartmental cooperation and coordination as faculty from different departments and wings worked together to resolve technical issues. Farm waste inves-

${ }^{26}$ J. S. Russell, “Magnates Back Cornstalk Mill," Des Moines Register, 12 January 1930, 19; Sweeney to Blackhills Mining and Industrial Association, Rapid City, South Dakota, 10 September 1931, Sweeney Papers; O. R. Sweeney's letter to the editor, Saturday Evening Post, 5 April 1940. 
tigations were no longer simply the province of chemical engineers, but of the college generally. ${ }^{27}$

Acceptance of agricultural waste research as a subject which required interdepartmental action broke down outdated jurisdictional barriers within the college and spurred communication among disciplines. A prime example of the new trend was a college-sponsored exploration of agriculturally derived "alcohol and other chemicals" as motor-fuel additives. In 1932 and 1933 the "Iowa State College Committee On the Use of Alcohol in Motor Fuels" conducted the research as an ad hoc body of eleven faculty members who represented four departments: chemistry, mechanical engineering, agricultural economics, and chemical engineering. The manner in which committee members approached their investigations was decisive and revealing. Unlike the chemical engineers' earlier efforts-in which they considered an entire industrial process from gathering the waste to establishing production facilities and techniques-committee members carefully divided tasks. Each department examined only those portions of the larger question which related to its special expertise. For instance, mechanical engineers performed mileage tests on alcohol-gasoline and acetone-gasoline blends. They also measured these substances for power output, influence on starting, and anti-knock values. Chemists' responsibilities were similarly circumscribed. They planned to survey the literature for other alcohol-gasoline tests, determine the miscibility of several alcohol-gasoline blends, and prepare various mixtures for the actual tests. In addition, they would compare the costs of producing alcohol from corn plants with that of producing it from a starch-grain-molasses equivalent. This type of research design was new at the college. Predicated upon the interdependence of faculty members, it defined "colleague" in a different way, as cross-disciplinary and functional. No single department dominated within this structure because each

${ }^{27}$ James E. Franken, “The Middlewest's Own Industry: Cornstalk Wallboard," Iowa Engineer 29 (1928), 3-4; J. B. Davidson and E. V. Collins, "Harvesting Cornstalks for Industrial Uses," Iowa Agricultural Experiment Station Bulletin \#274, (Ames, 1930); C. J. Peterson and R. M. Hixon, "Chemical Examination of the Tissue of the Cornstalk," Industrial and Engineering Chemistry, Analytical Edition 1 (1929); 65. Two bacteriology master's theses emerged during this period: Roger Patrick, "Bacteria Fermenting Xylan," 1929, and R. H. Carter, "Thermophilic Fermentation of Carbohydrates," 1929. 
brought a particular skill which seemed necessary for the problem at hand. thus this interdisciplinary research group was organized not hierarchically but functionally. Its existence signified the beginning of a new relationship between the college's previously separate wings. ${ }^{28}$

The chemical engineers' agricultural waste efforts had not alone effected that transformation. They had assistance from Raymond M. Hughes, who assumed the presidency of the college in September 1927. Hughes set the tone for interdisciplinary research. His major contribution was structural. He created a council on research and placed, as divisions within it, the Agricultural and Engineering Experiment Stations, the Industrial Science Research Institute, and the Veterinary Research Institute. By this administrative act, Hughes made clear that he considered research a common enterprise, which was unique among college activities. Hughes's reorganization divided the faculty into two segments, researchers and others, and that new explicit commonality gave researchers a reason for interdepartmental and interdivisional cooperation. ${ }^{29}$

The initial response to Hughes's realignment scheme was far from encouraging. Only a few faculty members engaged in even the most modest cooperative ventures. Professors in agriculture and industrial science studied land utilization patterns and formulated objectives for rural life. Also, within the agricultural experiment station, a social science section and a rural education subsection appeared. Although these efforts were interdepartmental and interdivisional, the rearrangement that Hughes had hoped to foster did not immediately occur collegewide. Interdivisional permutations included only agriculture and industrial science. Veterinary medicine and especially engineering continued to reside outside the new cooperative research nexus. Therefore making the coordinated research scheme a collegewide reality stood as the chemical engineers' major institutional achievement. To be sure, their significance also ex-

${ }^{28}$ For the division of responsibilities and plan for investigation see the foreword to "Use of Alcohol as Motor Fuel-Iowa State College," typescript, Iowa State University Library. This volume contains seven papers that constitute the results of the investigation.

${ }^{29}$ R. M. Hughes, Address ... September 23, 1927, 6-8 and September 22, 1928, 4, 6, 10. Also see Ross, A History, 357. 
tended to other areas. They had made chemical engineering important within the college and throughout the nation, and they showed the way for more broad-based, problem-oriented cooperative research endeavors. Their agricultural waste utilization program of the 1930s was the first instance in which engineering research emerged as an integral part of the college's new interdivisional program. In effect, they bridged the chasm which had separated engineering and agricultural wings in a new manner. While in the 1920 s the chemical engineers had chosen utilization of agricultural wastes as their primary industrial mission, it remained very much a department-based initiative. Only after 1930 did it lead to interdivisional action between engineering and agriculture faculty. Then, in the later 1930s, interdivisional problem-oriented research teams became de rigueur throughout Iowa State. The college's unique Corn Research Institute and its Swine Breeding Laboratory stand as the best known examples. ${ }^{30}$

Hughes certainly did his part to speed the diffusion of research teams throughout the college. Shortly after the project to make motor fuel from alcohol began, he addressed the faculty. He lauded interdivisional, problem-oriented research groups and celebrated the chemical engineers' role in creating the school's first such effort. He applauded the motor fuel study as an instance in which "departmental and divisional lines have been ignored" and he maintained that the practice had unleashed a "new institutional power. .. , the power of Iowa State College as a whole." He called on the college staff to replicate the process and conceive of Iowa State as a single "working unit." Although he acknowledged that "divisions and departments are necessary administrative units," Hughes concluded that they "are artificial." His explanation of the need for cooperation was simple: "Problems know no departmental lines." Their resolution usually required the union of "two or more departments, regardless of divisions," which would "work together from different angles and in frequent consultations." ${ }^{\text {"1 }}$

${ }^{30}$ R. M. Hughes, Address . . September 16, 1931, 17-18; C. F. Curtiss, "Report on Agricultural Research," Iowa Year Book of Agriculture, 1932, 145-147.

${ }^{31}$ R. E. Buchanan, "Report on Agricultural Research," Iowa Year Book of Agriculture, 1934, 353-355, 358-359; R. M. Hughes, Address ... September 18, 1935, 
Ironically, the chemical engineers' heyday ended just when they had achieved their greatest institutional significance. Two radically different problems occasioned their downfall. Their narrowly focused research program-corncobs in the early 1920s, cornstalks thereafter-had resulted in precious few commercial applications. Only the Maizewood process seemed commercially viable and that viability became questionable in the mid-1930s when the depression struck the housing industry particularly hard. Then federal financial support also became rare. The Bureau of Standards removed its research team in 1933 and the USDA relocated its agricultural by-products laboratory to Peoria a few years later. Even before the federal government withdrew support, there were indications that the chemical engineers recognized their plight. This realization did not cause them to abandon the idea that agricultural wastes could serve as industrial raw materials. Instead, they continued to follow, metaphorically if not literally, Sweeney's maxim "that there is more cash value in the elaborated stalk and cob than there is in the corn." Perhaps as an acknowledgement that the future of their waste utilization campaign hinged upon the immediate development of a commercially feasible product, the Ames group tried such varied agricultural wastes in the 1930 s as barley, wheat, flax, rice, and oat straw; cotton, banana, popcorn, broom corn, and tobacco stalks; rice, oat, and cottonseed hulls; swamp root; peanut and pecan shells; pineapple and Jerusalem artichoke tops; milkweed plants, tobacco stems, and sorghum cane bagasse; beet-sugar waste; and reeds, peat, and even chicken feathers. Yet while the chemical engineers considered a broad range of wastes throughout the decade and devoted special attention to cornstalk insulation board, furfural, and soybean oil, their new agricultural waste investigations did not bear fruit and their influence was on the wane. They had patented nineteen devices or processes from 1927 to 1935, but only one from 1938 to $1950 .{ }^{32}$

6, 24-25; Charles E. Friley, President's Address ... September 14, 1938, 2-3; lowa State Board of Education, Biennial Report, 1934, xxxi-xxxii, and 1936, LI-LIV.

${ }^{32}$ R. M. Hughes, Address . . September 20, 1933, 3-4 and Address . . September 19, 1934, 10; W. L. Bierring to Sweeney, 23 May 1938, and Sweeney to Fred 
Since they had not developed new commercially applicable processes and techniques from agricultural wastes, the chemical engineers lost their influence with industry. But the reason for their declining power within the college was far more subtle. The chemical engineers as a cohesive department, organized around the agricultural waste utilization campaign, fell victim to their own achievement, the interdepartmental, interdivisional research groups. Cooperative, problem-oriented research groups had transformed departmental coherence from a benison to an anachronism; departments focusing on only one arena, such as chemical manufacture from farm waste, had little utility within the new scheme. Problem-oriented research groups depended on specialists from different divisions and departments who would come together temporarily and devote their expertise to the particular question. Departmental coherence or homogeneity, then, was atavistic. Members of such departments could contribute to only a small fraction of college research activities. For a department to blossom or remain preeminent within this context its faculty had to possess a wide range of specialties and thus be able to participate in many research groups. Only through the participation of a department's individual members on numerous research teams could the department stand tall within the "new" college.

The chemical engineers found themselves between a rock and a hard place. To regain industrial support they would have to de-

E. Butcher, 8 July 1943, Sweeney Papers. Sweeney's comment was reported in Wheele McMillen, "Uses Now Found for Agricultural Waste," New York Times, 2 October 1927, 14. For brief reports of the chemical engineers' broadgauged research in the early 1930 s see Sweeney to L. J. Dickinson, 10 December 1931; Sweeney to E. Jerome Dyer, 9 July 1939, 26 July 1937, 30 March 1931; and Sweeney to Waldemar Kaempfert, 16 July 1934, all in Sweeney Papers. See also USDA, Bureau of Chemistry and Soils, Report of the Chief, 1932, 14; and Arnold, "Utilization of Agricultural Wastes and Surpluses," 9. Representative theses from the 1930s included P. N. Burkhart and Dan M. Harrison, "Studies in the Extraction of Soybean Oil with N-Butyl Alcohol," 1937; H. F. Conway and J. J. Wayler, "Furfural as a Paint and Varnish Remover," 1937; R. B. Menzel and P. F. Seeling, "The Destructive Distillation of Alkali Lignin," 1937; Carl A. Holmberg, "The Effect of Composition on the Drying Rate of Corn Board," 1939; James Dustin and Harold Heap, "Emulsions of Furfural and Their Uses," 1938; and Arnold L. Ayres, "A Soybean Furfural Urea Plastic," 1938. The only patent received between 1936 and 1950 by a chemical engineer was O. R. Sweeney, Matboard Handing Machine, 1937, US Patent Office \#2,084,980. 
velop new commercial agricultural waste utilization processes and techniques, but to recapture primacy in the college they would have to broaden their interests significantly to cooperate with many research groups. Before World War II the chemical engineers attempted to do both and accomplished neither. In 1937, and for the first time during Sweeney's tenure at Iowa State, only a minority of students selected farm waste thesis topics. This trend persisted through 1941, but the apparent shift away from almost exclusive emphasis on agricultural waste research did not give the chemical engineers immediate entry into the reconstituted college community. Department members virtually disappeared from publications of the engineering experiment station and extension service. Between 1938 and 1949, the chemical engineers contributed only a single bulletin. ${ }^{33}$

World War II interrupted the chemical engineers' search for a renewed mission. They did not reestablish industrial ties or become integrated within the college. The pace of agricultural waste work quickened somewhat during this period but it differed strikingly from earlier research; it shunned long-range prospects and focused on immediate benefits. Its goal was not to boost farm incomes but, in a period marked by shortages and rationing, to turn readily retrievable wastes into useful products. Rather than consider conventional agricultural commodities, the chemical engineers attempted to derive industrial substances from temporary, war-related crop wastes. Hemp and milkweed refuse received the most attention. Japanese occupation of the Philippines had cut off America's supply of hemp rope, while demand for milkweed floss sharply increased because of its use in airplane acoustical tiles. Hemp-hurd research came first. The chemical engineers proved they could produce insulation boards of passable quality from hurds. They even prevailed on Maizewood to manufacture some to see how the process functioned on an industrial scale. Only later in the war

\footnotetext{
${ }^{33}$ In 1937, only fifteen of thirty-four students selected thesis topics concerning agricultural wastes. By 1939, the percentage had decreased even further. Only 19 of 46 students pursued farm-waste studies. The only bulletin during this decade was O. R. Sweeney and L. K. Arnold, "Plastics from Agricultural Materials,"'Iowa Engineering Experiment Station Bulletin \#154 (Ames, 1942). Also in 1938, the chemical engineering department no longer could claim the greatest number of graduate students within the division. See Iowa State Board of Education, Biennial Report, 1938, 314.
} 
did they take up milkweed seed. After a number of tests, they had difficulty finding a use for the material. The war concluded before they resolved the problem. With the war at an end, they dropped their attempts to develop an application for the milkweed seeds and turned away from hemp-hurd investigations. ${ }^{34}$

After the war, the chemical engineers' research efforts became much more diverse. Only Sweeney and Arnold continued agricultural waste investigations and they limited their inquiries sharply to cornstalk insulation board, furfural, and soybean oil. Each of the department's other members went in a different direction. Even Webber abandoned agricultural wastes and specialized in unit operations. Sweeney resigned as department chairman in 1947; his department had outgrown his leadership. It had chosen to become a department of many specialties and part of the integrated college. ${ }^{35}$

Any assessment of Iowa State's chemical engineers during the interwar period must conclude that their agricultural waste utilization campaign paid farmers few immediate benefits. Farm wastes did not serve in the 1920s and 1930s as the source of raw materials of entire industries; kernels remained more valuable than cobs and stalks. Despite this failure, the chemical engineers had accomplished much institutionally. Their research helped put lowa State College on the map. It gave the school an international reputation and attracted investment from the federal government and private enterprise. Their research program also served as a base around which to organize the college faculty. In the 1920s, it bridged the gap between Iowa State's competing engineering and agricultural wings and its contributions were even greater in the next decade. The chemical engineers paved the way for the creation of interdisciplinary and interdivisional

${ }^{34}$ Kent Knutson, "Fibers for Wars," Iowa Engineer 44 (1944), 117; Roger Williams, "Profit in Floss," Iowa Engineer 45 (1945), 177; Boris Berkman to Sweeney, 23 January 1945, and 10 April 1945; Sweeney to W. J. Schlick, 3 November 1944; Sweeney to Johart Larwill, 27 June 1946, all in Sweeney Papers; Iowa State Board of Education, Biennial Report, 1942, 20.

${ }^{35}$ For Sweeney's and Arnold's work after the war, see, for example, O. R. Sweeney and L. K. Arnold, "Moisture Relations in the Manufacture and Use of Insulating Board," Iowa Engineering Experiment Station Bulletin \#163 (Ames, 1948); O. R. Sweeney, L. K. Arnold, and E. G. Hollowell, "Extraction of Soybean Oil by Trichloroethylene," Iowa Engineering Experiment Station Bulletin \#165 (Ames, 1949); and O. R. Sweeney and L. K. Arnold, "Furfural Utilization Studies," Iowa Engineering Experiment Station Bulletin \#169 (Ames, 1950). 
research groups. Institutional reformation was no small matter. In this sense the chemical engineers did indeed aid farmers, though not immediately and not in the manner proposed. While their agricultural waste investigations did not boost farm incomes, the chemical engineers' cooperative research served as a model by which the college faculty could tackle large multidimensional problems. After the chemical engineers' pathbreaking efforts, the college repeatedly formed interdisciplinary, interdivisional research teams. Today they remain the heart of the modern university. 
Copyright of Annals of Iowa is the property of State of Iowa, by \& through the State Historical Society of Iowa and its content may not be copied or emailed to multiple sites or posted to a listserv without the copyright holder's express written permission. However, users may print, download, or email articles for individual use. 